\title{
FAKTOR PENGHAMBAT DALAM MENGAKSES PEMBIAYAAN PADA PENGUSAHA MIKRO DI KARESIDENAN MADIUN: SECOND ORDER CFA
}

\author{
Hartomi Maulana \& Mohammad Zaenal Abidin \\ Universitas Darussalam Gontor \\ E-mail: mhartomi@unida.gontor.ac.id
}

\begin{abstract}
ABSTRAK
Pemerintah memperbanyak bank yang khusus untuk menyediakan pinjaman mikro, tapi masih banyak usaha mikro yang masih mengalami kesulitan dalam mengakses jasa keuangan. Tujuan penulisan laporan ini adalah untuk mengukur faktor penghambat pelaku usaha mikro dalam mengakses pembiayaan dari layanan jasa perbankan di wilayah karesidenan Madiun Raya. Di antara faktor penghambat dalam pembiayaan terdapat kelayakan yang kompleks, aksesibilitas yang rendah dan faktor agama. Penelitian ini lebih jauh menguraikan tiga faktor penghambat dengan menggunakan Second-order Confirmatory Factor Analysis (CFA) untuk memvalidasi faktor tersebut. Pendekatan kuantitatif diterapkan dalam penelitian ini dalam mencapai tujuan yang dimaksud. Studi ini menggunakan data primer yang dikumpulkan melalui kuesioner dengan melibatkan 146 responden yang mempunyai usaha mikro yang terpilih di sekitar wilayah Madiun Raya yang meliputi Magetan, Ngawi, Ponorgo dan Madiun. Structural Equation Modelling (SEM) dalam hal ini second-order CFA digunakan sebagai teknik analisis. Studi mengungkapkan bahwa second order CFA memvalidasi tiga variabel yang meliputi faktor agama, aksesibilitas yang rendah dan kelayakan yang rendah berada dalam fit indices yang terbaik sebagai faktor penghambat pembiayaan pada jasa keuangan di karisedenan Madiun. Berdasarkan hasil tersebut, memungkinkan akademisi dan peneliti untuk mengetahui faktor-faktor yang dapat mencegah usaha mikro dalam mengakses pembiayaan dalam konteks lembaga perbankan Indonesia.
\end{abstract}

Kata Kunci: faktor penghambat pembiayaan, UMKM, Madiun Raya, BPS, EFA, Second Order CFA

JEL Classification: $G, G 2, G 21$

\begin{abstract}
This paper examines factors that may hinder micro, small and medium enterprises (MSMEs) in accessing financing from banking services in the area of Madiun Raya. Among barrier access to finance factors is complicated eligibility, low accessibilities and religious factors. However, this study further highlights three factors of barrier access to finance by using Second-order Confirmatory Factor Analysis (CFA) to validate these factors. In achieving the objectives, a quantitative approach was applied in this study. This study uses primary data collected through a questionnaire involving 146 selected respondents who have micro businesses around the Madiun Raya area which includes Magetan, Ngawi, Ponorgo, Madiun and Madiun Kota. Structural Equation Modeling (SEM) in this case, second-order CFA is used as an analysis technique. The study revealed that second order CFA validates three variables which include religious factors, low accessibility and low eligibility are in the best fit indices as factor of access barrier to finance to financial services around Madiun raya area. With the results of this study, it allows academics and researchers to find out the factors that can prevent micro businesses in accessing finance in the context of Indonesian banking institutions.
\end{abstract}

Keyword: factor of barrier access to finance, MSMEs, Madiun Raya, BPS, EFA, Second Order CFA

JEL Classification: $G, G 2, G 21$ 


\section{PENDAHULUAN}

Data Badan Pusat Statistik (BPS) menunjukkan sekitar 26,58 juta orang miskin di Indonesia dan sekitar 4.4 juta orang miskin tinggal di Jawa Timur (BPS, 2017). BPS melaporkan 16,5 persen dari total penduduk Indonesia tinggal di Jawa Timur (BPS, 2017). Hal ini mengindikasikan secara tidak langsung mereka memberikan kontribusi yang signifikan terhadap tingkat kemiskinan nasional. Mayoritas mata pencarihan mereka sangat bergantung pada sektor informal seperti usaha mikro yang berkonsentrasi pada sektor pertanian dan perdagangan. Kegiatan dalam sektor riil ini terus menjadi pusat perhatian pembangunan ekonomi Indonesia bagi masyarakat miskin dan kesuksesan mereka berpotensi menghasilkan pertumbuhan pendapatan dan pengentasan kemiskinan.

Terkait dengan masalah kemiskinan, beberapa program pemerintah berusaha meningkatkan akses terhadap layanan keuangan melalui program keuangan mikro, misalnya penyediaan Kredit Usaha Rakyat (KUR), memperbanyak bank yang khusus untuk menyediakan pinjaman mikro seperti Bank Perkreditan Rakyat (BPR) dan sebagainya. Namun, masih banyak usaha mikro yang masih mengalami kesulitan dalam mengakses jasa keuangan. Menurut data Bank Indonesia, alokasi kredit untuk usaha mirko-kecil dan menengah didominasi oleh usaha menengah sekitar 65 persen dari total kredit, diikuti dengan usaha kecil sekitar 29 persen sementara usaha mikro hanya menerima 6 persen dari total kredit yang dialokasikan untuk segmen ini (World Bank, 2011). Hal ini mengindikasikan bahwa usaha mikro mempunyai keterbatasan akses terhadap pelayanan kredit yang mana ini boleh mencegah mereka untuk mencapai kapasitas maksimum. Kondisi ini dapat mempengaruhi jutaan orang miskin terutama di Jawa Timur (World Bank, 2011). Timbul pertanyaan, faktor apa yang menghalangi akses mereka terhadap pembiayaan dari jasa keuangan? Studi ini bertujuan untuk menganalisis faktor penghambat usaha mikro dalam mengakses pembiayaan di wilayah karisedenan madiun dan sekitarnya. Wilayah karesidenan madiun yang meliputi Madiun, Madiun Kota, Ngawi, Magetan dan Ponorogo dipilih karena wilayah ini terdapat sekitar 368,130 usaha mikro dan kecil atau sekitar 8 persen dari total usaha mikro di Jawa Timur yang saat ini berjumlah sekitar 4,5 juta lebih (BPS, 2016).

Mengidentifikasi faktor yang menghambat akses kredit adalah sebuah percobaan yang penting dalam meningkatkan keuangan inklusif. Faktor penghambat seperti yang diungkapkan oleh Demirguc-Kunt et al. (2008) adalah faktor keterjangkauan yang rendah (e.g. pengenakan biaya administrasi dan bunga yang tinggi), faktor persyaratan yang rumit (e.g. jaminan asset dan persyaratan dokumen yang sulit), faktor aksesibilitas yang rendah (i.e. jarak yang jauh untuk akses pelayanan keuangan), faktor ketersediaan produk keuangan mikro yang terbatas (e.g. produk keuangan yang tidak tersedia untuk semua segmen), dan faktor agama (e.g. produk keuangan yang mengandungi bunga (Riba). Studi 


\section{Hartomi Maulana}

\section{Mohammad Zaenal Abidin}

ini lebih mengelaborasi hambatan ini sebagai 3 faktor dengan menggunakan second-order confirmatory factor analysis (second order CFA). Studi sebelumnya yang terkait dengan penghambat akses terhadap pembiayaan adalah bersifat deskriptif (World Bank, 2011; Mahmud \& Huda, 2010). Oleh karena itu, studi ini mencoba menganalisis faktor penghambat yang teridentifikasi dengan menggunakan second-order CFA untuk memvalidasi faktor-faktor tersebut.

\section{TINJAUAN PUSTAKA}

Beberapa studi mengungkapkan bahwa di antara faktor utama penghambat pembiayaan adalah keterjangkauan yang rendah (biaya layanan dan tingkat suku bunga tinggi), kelayakan yang kompleks (jaminan yang tidak fleksibel dan persyaratan dokumen yang rumit), aksesibilitas rendah (akses fisik), dan ketersediaan produk terbatas atau kurangnya berbagai macam produk keuangan (produk keuangan yang disediakan bukan untuk semua segmen) (Demirguc-Kunt et al., 2008; Ledgerwood \& Gibson, 2013).

Bahkan faktor agama juga di pertimbangkan sebagai salah satu faktor penghambat pembiayaan. Beberapa nasabah muslim melihat bahwa produk keuangan konvensional mengandung bunga atau riba yang memang dilarang oleh prinsip keuangan Islam (Karim et al., 2008). Maka dari itu, meskipun mereka mempunyai akses tetapi tidak akan memilih jenis produk tersebut. Bank Indonesia (2000) melaporkan 49 persen penduduk pedesaan sadar bahwa bunga dilarang dan akan memilih produk keuangan yang berbasis bebas bunga (OIC Outlook Series, 2012).

Tingkat bunga yang terjangkau merupakan salah satu faktor penting untuk menarik konsumen dalam lembaga keuangan. Biaya transaksi yang tinggi merupakan salah satu hambatan utama dalam mengakses pembiayaan. Dari perspektif perbankan, transaksi yang sangat kecil menyebabkan biaya overhead yang tinggi. Apalagi jika mereka beroperasi di lokasi terpencil dengan sedikit transaksi keuangan yang mahal dan mungkin tidak layak (Jha et al., 2014). Sebuah survei yang dilaporkan oleh ICS (Investment Climate Surveys) pada tahun 2002, menunjukkan sebagian besar usaha kecil tidak meminjam pada perbankan karena bunga yang tinggi (Demirguc-Kunt et al., 2008).

Persyaratan kelayakan yang kompleks bisa menjadi faktor utama penghambat pembiayaan. Untuk maksud penilailan, dalam menawarkan pembiayaan perbankan biasanya mensyaratkan beberapa dokumen seperti KTP, slip gaji atau bahkan sertifikat tanah sebagai agunan. Aksesibilitas terbatas merupakan salah satu faktor penghambat pembiayaan. Hal ini dapat dihambat dengan jarak yang jauh ke outlet perbankan (Beck et al., 2008). 


\section{Jurnal Manajemen Teori dan Terapan \\ Tahun 12. No. 3, Desember 2019}

Isu budaya dan agama mungkin bisa menjadi tantangan untuk meningkatkan keuangan inklusif. Budaya dan agama dianggap sebagai faktor signifikan untuk membentuk sikap individu terhadap perilaku niat dan preferensi (DeLamater \& Myers, 2011). Bahkan-meski beberapa kelompok berpenghasilan rendah memiliki akses namun mereka memilih untuk tidak menggunakan layanan keuangan karena alasan agama. Ini karena produk yang diberikan mungkin mengandung unsur-unsur yang dilarang oleh Islam. Unsur-unsur ini termasuk riba, perjudian (maisir) dan ambiguitas berlebih (gharar).

Kajian Investment Climate Survey (ICS) pada tahun 2002 menyoroti alasan usaha mikro tidak menggunakan pembiayaan bank (Demirguc-Kunt et al., 2008). ICS mengungkapkan bahwa sebagian besar pelaku usaha mikro tidak memerlukan pembiayaan. Selain itu, mereka dikecualikan dari pembiayaan bank karena tingginya suku bunga, persyaratan agunan yang ketat dan prosedur memohon yang rumit. Alasan lain yang dilaporkan tidak nyaman dengan bank, lokasi yang jauh dan tidak punya dokumen (Demirguc-Kunt et al., 2008).

Namun studi tentang penghambat pembiayaan dari layanan keuangan formal di Indonesia masih terbatas. Penelitian sebelumnya dibatasi dalam lingkup studi deskriptif. Survei yang dilakukan Bank Indonesia (2005) misalnya menemukan bahwa akses terhadap pembiayaan usaha mikro kecil masih menjadi masalah karena beberapa alasan termasuk persyaratan dokumen yang rumit, kurangnya agunan, dan tingkat suku bunga yang lebih tinggi (World Bank, 2011). Bank Dunia pada tahun 2006 menemukan bahwa biaya kredit merupakan kendala utama yang dihadapi oleh usaha mikro dan kecil di pedesaan Indonesia dalam mengakses pembiayaan (World Bank, 2010). Kendala lain seperti persyaratan agunan, kompleksitas dan biaya prosedur aplikasi, dan kurangnya dokumentasi juga diidentifikasi (World Bank, 2010). Mahmud dan Huda (2010) mengungkapkan bahwa hampir setengah dari UKM yang mereka survei tidak memiliki akses terhadap keuangan karena biaya transaksi sangat mahal, persyaratan agunan tidak mencukupi dan kurangnya administrasi yang baik. Meskipun, beberapa studi tentang akses penghambat pembiayaan dilakukan, sedikit studi yang mengidentifikasi faktor penghambat yang menggunakan second order CFA untuk memvalidasi faktor tersebut. Gambar 1 dibawah ini menggambarkan faktor penghambat secara ringkas.

\section{METODE}

Pendekatan kuantitatif di gunakan dalam studi ini. Struktur faktor yang mendasari 14 indikator terkait dengan pengukuran faktor penghambat pembiayaan diuji. Pengukuran skala faktor penghambat pembiayaan terdiri dari tiga variabel yaitu kelayakan yang rendah, aksesiblitas yang rendah dan faktor agama. 


\section{Hartomi Maulana}

\section{Mohammad Zaenal Abidin}

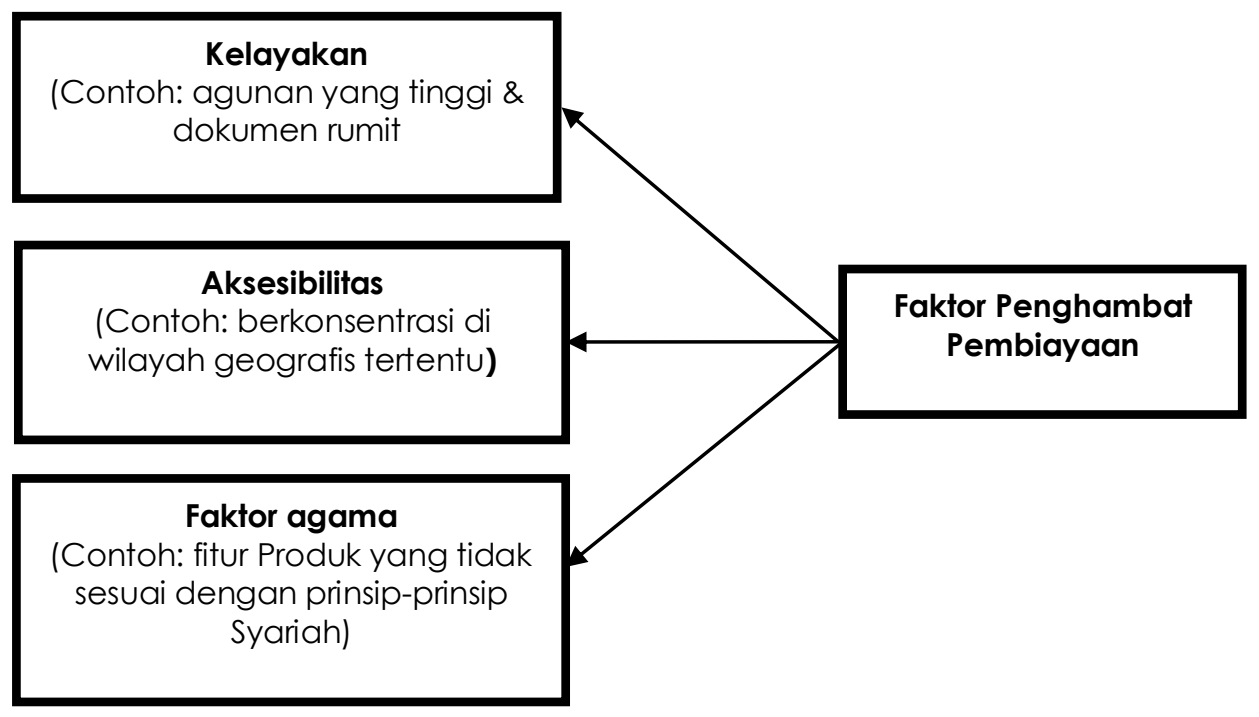

Figure 1.

Faktor Penghambat Pembiayaan

Indikator yang terdiri dari sub-skala yang mendasarinya disesuaikan dan dimodifikasi sesuai kebutuhan studi yang diambil dari Demirguc-Kunt et.al (2008) dan Demirguc-Kunt \& Klapper (2012). Data dikumpulkan dengan kuesioner yang di distribusikan ke beberapa responden terpilih yang mempunyai usaha mikro di wilayah karisedenan Madiun. Kuesioner dikembangkan dengan menggunakan Skala Likert 5 poin, mulai dari 1 = sangat tidak setuju hingga 5 = sangat setuju.

Dalam studi ini, dari 300 kuesioner yang didistribusikan, 211 dikembalikan dengan tingkat responsif 70 persen. Namun, sekitar 65 data dihilangkan karena tidak memenuhi persyaratan pemenuhan untuk digunakan sebagai sampel seperti pengisian tidak lengkap, outlier dan sebagainya. Dengan demikian, ukuran sampel akhir yang digunakan dalam studi ini adalah 146, dan tingkat responsif yang disesuaikan adalah 48 persen.

Teknik analisis yang digunakan adalah Second order Confirmatory Factor Analysis (CFA) yang merupakan bagian dari Structural Equation Modelling (SEM). CFA yang diuji melalui keseluruhan model pengukuran menggabungkan keseluruhan konstruks yang diekstrak dari factor analysis. Pilihan CFA muncul dari relevansinya untuk mengakomodasi beberapa variabel laten. Selain itu, CFA adalah teknik yang paling tepat digunakan untuk mengukur instrumen yang telah dikembangkan, dan struktur faktor mereka divalidasi (Byrne, 2010), sesuai dengan tujuan studi ini. Di antara studi sebelumnya yang menerapkan CFA adalah Milfont and Duckit (2004), Adewale et al. (2012) dan Mustapha dan Bolaji (2015). 


\section{HASIL DAN DISKUSI}

\section{Demografi Responden}

Tabel 1 dibawah adalah gambaran profil responden secara ringkas. Mayoritas responden merupakan laki-laki dengan frekuensi sebesar 93 (63.7 persen), sedangkan responden perempuan sebesar 53 (36.3 persen). Tabel juga menunjukkan bahwa sebanyak 91 responden (62.3 persen) sudah menikah. Kategori umur 20-29 tahun dan 30-39 tahun masingmasing mencatatkan 39 persen dan 29.5 persen dan umur diatas 40 tahun tercatat 25 persen. Bersadarkan agama, 94.5 persen responden beragama Islam dan yang lainya Protestan (3.5 persen) and Katolik (2.1 persen). Data dalam tabel menunjukkan bahwa sekitar 33.6 persen lulusan S1, diikuti dengan lulusan SMA sebesar 30 persen dan SMP sebesar 12.3 persen. Bagaimanapun, hanya 7 persen responden tidak lulus SD.

Tabel 1.

Profil Responden

\begin{tabular}{|c|c|c|}
\hline Gender & Frekuensi & Persen (\%) \\
\hline Laki-Laki & 93 & 63.7 \\
\hline Perempuan & 53 & 36.3 \\
\hline \multicolumn{3}{|l|}{ Status } \\
\hline Bujang & 55 & 37.7 \\
\hline Menikah & 91 & 62.3 \\
\hline \multicolumn{3}{|l|}{ Umur } \\
\hline 20 Tahun ke bawah & 9 & 6.2 \\
\hline 20-29 Tahun & 57 & 39.0 \\
\hline 30-39 Tahun & 43 & 29.5 \\
\hline 40 Tahun ke Atas & 37 & 25.3 \\
\hline \multicolumn{3}{|l|}{ Agama } \\
\hline Islam & 138 & 94.5 \\
\hline Katolik & 3 & 2.1 \\
\hline Protestan & 5 & 3.5 \\
\hline \multicolumn{3}{|l|}{ Pendidikan } \\
\hline Tidak Ada & 7 & 4.8 \\
\hline SD & 16 & 11.0 \\
\hline SMP & 18 & 12.3 \\
\hline SMA & 44 & 30.1 \\
\hline Diploma & 5 & 3.4 \\
\hline Sarjana & 49 & 33.6 \\
\hline Master & 7 & 4.8 \\
\hline \multicolumn{3}{|c|}{ Sumber pendapatan utama dari usaha? } \\
\hline Ya & 83 & 56.8 \\
\hline Tidak & 63 & 43.2 \\
\hline
\end{tabular}

Saat ditanya tentang sumber pendapatan utama, 57 persen responden menjawab bahwa sumber pendapatan utama mereka dari bisnis mereka sendiri dan 43 merespons tidak. Sumber pendapatan mereka selain dari bisnis, juga dari bekerja sebagai pekerja swasta, PNS, guru / dosen dan sebagaianya. 


\section{Hartomi Maulana}

\section{Mohammad Zaenal Abidin}

\section{Factor Analysis \& Reliability Test}

Sebelum melakukan second order CFA, Exploratory Factor Analysis (EFA) digunakan dalam studi ini. Factor analysis and reliability test digunakan untuk mengecek validitas dan reliabilitas data. Factor analysis menunjukkan tes validitas, sedangkan reliability test mengevaluasi konsistensi setiap item dalam kuesioner. Hasil factor analysis mengkonfirmasi validitas dari beberapa variabel yang di studi seperti kelayakan yang rendah, aksesibilitas yang rendah dan faktor agama. Factor analysis dengan varimax rotation di implementasikan untuk mengangkat keunikan variabel-variabel tersebut. Sebelum melakukan factor analysis, Bartlett test of Sphericity $(p<0.05)$ and Kaiser-Meyer-Olin $(K M O)$ di cek. Nilai KMO yang dapat diterima seharusnya 0.5 keatas. Ekstraksi factor analysis dilakukan dengan menggunakan principal component analysis (PCA) dengan varimax rotation (Hair et al., 2010).

Factor analysis pada awalnya dilakukan dengan semua 14 indikator dalam kuesioner. Uji Barther's Sphericity secara statistik signifikan (Chi-Square $=1715.71, p=0,000$ ) dan hasil KaiserMeyer-Olkin (KMO) dapat diterima (0.833>0.50). Namun, split loading ditemukan pada item 'LYK4' (Tidak punya pendaptan tetap), 'LYK5' (Ketidakpercayaan bank kepada kelompok berpendapatan rendah) dan cross loading pada item 'AKS4' (Tidak memiliki pengetahuan tentang prosedur perbankan). Jadi, iterasi berikutnya diperlukan dengan mengabaikan item-item tersebut.

Tabel 2.

KMO and Bartlett's Test

\begin{tabular}{lll}
\hline Kaiser-Meyer-Olkin Measure of Sampling Adequacy. & 0.872 \\
\hline Bartlett's Test of Sphericity & Approx. Chi-Square & 1564.99 \\
& df & 55 \\
& Sig. & 0.000 \\
\hline
\end{tabular}

Setelah iterasi kedua dilakukan seperti disajikan pada tabel diatas, hasil nilai Kaiser-MeyerOlkin (KMO) menunjukkan pada tingkat yang dapat diterima 0.872 dan Bartlett's Test of Sphericity juga menghasilkan signifikansi statistik (0.000), yang mengindikasikan faktor dari matriks korelasi. Demikian, analisis faktor dilanjutkan untuk melakukan analisis komponen utama (PCA) dan rotasi varimax dengan normalisasi Kaiser dan hasil digambarkan pada tabel 3.

Seperti yang disajikan pada Tabel 3, hasil factor analysis mengidentifikasi 3 faktor dengan menghasilkan signifikan factor loading dan indikator eigenvalve sesuai dengan nilai batas yang direkomendasikan oleh Hair et al. (2010) yaitu lebih dari 1. Indeks communality dapat diterima berkisar antara 0.704 dan 0.927 . Hasil juga mengungkapkan bahwa tiga faktor laten 
telah berhasil diekstraksi dari sebelas indikator; menjelaskan $83.343 \%$ dari total varian. Variabel 1 dan 2 masing-masing memiliki 4 indikator, sedangkan variabel 3 memiliki 3 indikator. Factor loading pada indikator-indikator tersebut berkisar antara 0.542 dan 0.930 . Tabel 3 juga menunjukkan koefisen reliabilitas variabel. Nilai reliabilitas yang diukur melalui nilai Cronbach alpha (a) mengindikasikan pada tingkatan yang dapat diterima yaitu diatas 0.70 (Nunnally \& Bernstain, 1994). Oleh karena itu, isu reliabilitas tidak ditemukan dalam studi ini.

Tabel 3.

Factor Analysis

\begin{tabular}{|c|c|c|c|c|c|c|}
\hline \multirow[b]{2}{*}{ Kode } & \multirow[b]{2}{*}{ Indikator } & \multicolumn{3}{|c|}{ Faktor } & \multirow[b]{2}{*}{$\begin{array}{l}\text { Commu } \\
\text { nalities }\end{array}$} & \multirow[b]{2}{*}{$\begin{array}{r}\text { Cronbach } \\
\text { alpha }\end{array}$} \\
\hline & & \begin{tabular}{l}
1 \\
\multicolumn{1}{c}{1} \\
Faktor \\
agama
\end{tabular} & \begin{tabular}{l}
\multicolumn{1}{c}{2} \\
Aksesibilito \\
s rendah
\end{tabular} & $\begin{array}{l}\text { 3 } \\
\text { Kelayakan } \\
\text { rendah }\end{array}$ & & \\
\hline LYK1 & $\begin{array}{l}\text { Mensyaratkan dokumen } \\
\text { yang rumit (seperti slip gaji, } \\
\text { bukti domisili dsb.) }\end{array}$ & & & 906 & .902 & .873 \\
\hline LYK2 & $\begin{array}{l}\text { Mensyaratkan jaminan yang } \\
\text { ketat seperti sertifikat, BPKB } \\
\text { kendaraan dsb., }\end{array}$ & & & .853 & .885 & \\
\hline LYK3 & Mensyaratkan pembatasan usia & & & .542 & .704 & \\
\hline AKS 1 & Jarak yang jauh ke bank & & .770 & & .798 & .873 \\
\hline AKS2 & $\begin{array}{l}\text { Tidak ada / jauh dari outlet } \\
\text { ATM }\end{array}$ & & .764 & & .761 & \\
\hline AKS3 & Persepsi ditolak masuk bank & & .730 & & .729 & \\
\hline AKS5 & Staf bank yang kurang ramah & & .815 & & .842 & \\
\hline SHAl & Pinjaman bunga & .869 & & & .918 & .953 \\
\hline SHA2 & $\begin{array}{l}\text { Produk keuangan } \\
\text { mengandungi gharar }\end{array}$ & .888 & & & .927 & \\
\hline SHA3 & $\begin{array}{l}\text { Produk keuangan } \\
\text { mengandungi maysir }\end{array}$ & .930 & & & .921 & \\
\hline SHA4 & $\begin{array}{llr}\text { Keadilan dari } & \text { produk } \\
\text { keuangan adalah elemen } \\
\text { yang penting } \\
\text { kepatuhan syariah }\end{array}$ & .735 & & & .780 & \\
\hline & $\begin{array}{l}\text { Eigenvalue } \\
\text { Percent of variance } \\
\text { Cumulative (\%) }\end{array}$ & $\begin{array}{c}6.645 \\
31.839 \\
31.839\end{array}$ & $\begin{array}{c}1.378 \\
28.414 \\
60.253\end{array}$ & $\begin{array}{c}1.144 \\
23.090 \\
83.343\end{array}$ & & \\
\hline
\end{tabular}

\section{Second Order Confirmatory Factor Analysis (CFA)}

Second order CFA digunakan setelah EFA dibahas dalam bagian sebelumnya. Second order CFA ini digunakan untuk menvalidasi faktor penghambat pembiayaan dari segi convergent validity dan diskriminan setelah komponen tersebut diidentifikasi dari EFA (Byrne, 2010).

Convergent validity memproses sejauh mana setiap item dalam konstruk yang mendasari mempunyai andil dalam proporsi yang sama dengan item lain dalam konstruk yang sama (Hair et al., 2010). Hair et al. (2010) menjelaskan ada tiga cara dalam menentukan 


\section{Hartomi Maulana}

\section{Mohammad Zaenal Abidin}

convergent validity yaitu standard factor loading, the average variance extracted (AVE) and construct reliability (CR). Standardized factor loading menunjukkan hubungan antara item dan konstruk laten sedangkan average variance extracted mengindikasikan sejauh mana item-item tersebut bertemu di antara konstruk yang sama. Construct reliability digunakan dalam mengukur sejauh mana variabel yang mendasari konstruk dan itemitemnya diwakili dalam structural equation modelling (SEM).

Table 4.

Convergent Validity

\begin{tabular}{lll}
\hline Constructs & CR & AVE \\
\hline Kelayakan (LYK) & 0.900 & 0.754 \\
Aksesibilitas (AKS) & 0.877 & 0.644 \\
Faktor agama (SHA) & 0.973 & 0.900 \\
\hline Statistik & Batas \\
\hline Composite Reliability (CR) & $>0.6$ \\
Average Variance Extracted (AVE) & $>0.5$ \\
Convergent Validity & AVE $>0.5$ \\
\hline
\end{tabular}

Seperti yang disajikan pada Tabel 4, semua konstruk telah mencapai nilai ambang batas untuk CR di atas 0.6 dan AVE di atas 0.5 (Hair et al., 2010). Setelah convergent validitas terpenuhi, berikutnya adalah menguji kelayakan model (goodness of fit) dari second order CFA. Dibawah ini adalah gambaran secara ringkas second order CFA.

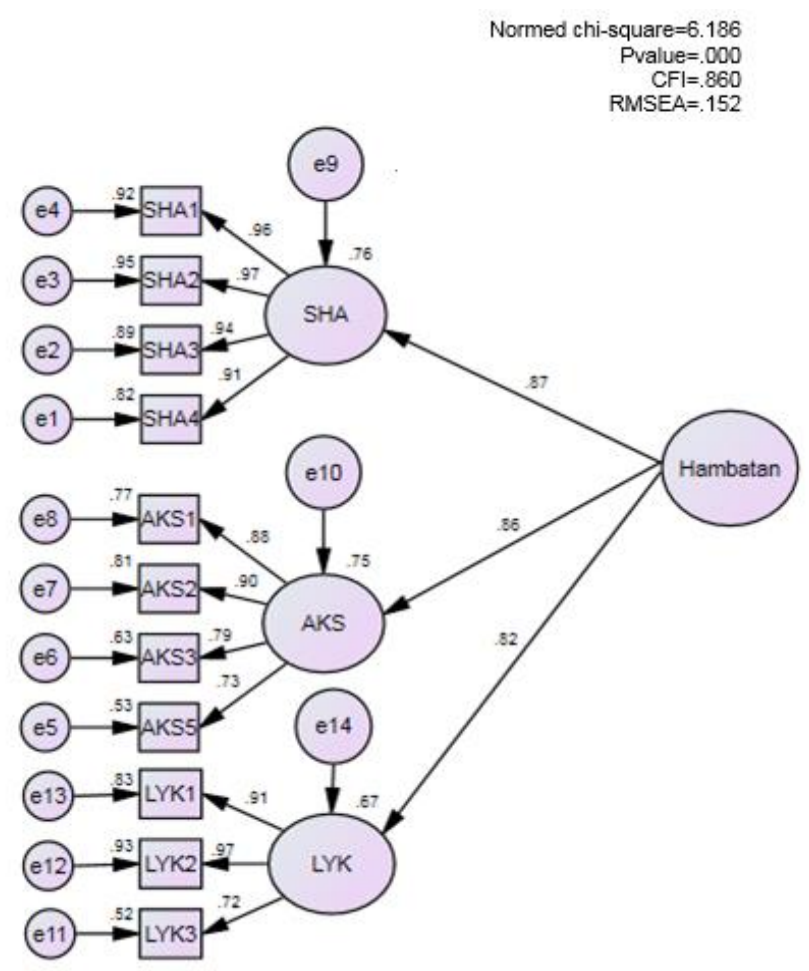

Figure 2.

Second order CFA penghambat pembiayaan (percobaan 1) 
Berdasarkan Gambar 2, hasil percobaan 1 menunjukkan model belum fit dimana hasil uji kelayakan model belum mencapai goodness of fit indices yang diinginkan sesuai dengan cut-off value yang diharapkan. Normed Chi-Square (x2 / df) = 6.186 lebih tinggi dari yang seharusnya dibawah 5, CFI $=0.860$ lebih rendah dari yang seharusnya diatas 0.90 (Hu \& Bentler, 1999) dan RMSEA $=0.152$ jauh diatas ambang yang ditentukan yang seharusnya kurang dari 0.10 (Hu \& Bentler, 1999).

Berikutnya, modifikasi diperlukan untuk memperbaiki nilai goodness of fit indices. Dalam hal ini, modifikasi dilakukan berdasarkan nilai indeks modifikasi (MI) yang yang dihasilkan pada output AMOS. Indeks modifikasi di cek untuk melihat adanya korelasi tinggi diantara observed variable (Byrne, 2010). Penerapan item-item yang mempunyai kovarian tinggi dengan inter-korelasi, goodness of fit indices mengalami perbaikan dan memenuhi cut-off value yang diharapkan (Normed Chi-Square $(X 2 / \mathrm{df}$ ) $=3.683, \mathrm{CFI}=0.943, \mathrm{RMSEA}=0.098$ ) seperti disajikan secara ringkas pada Gambar 3 (Percobaan ke-2). Sehingga dapat disimpulkan bahwa penilaian keseluruhan kriteria pada model fit dapat diterima pada 11 items penghambat pembiayan menggunakan second order CFA dalam validasinya.

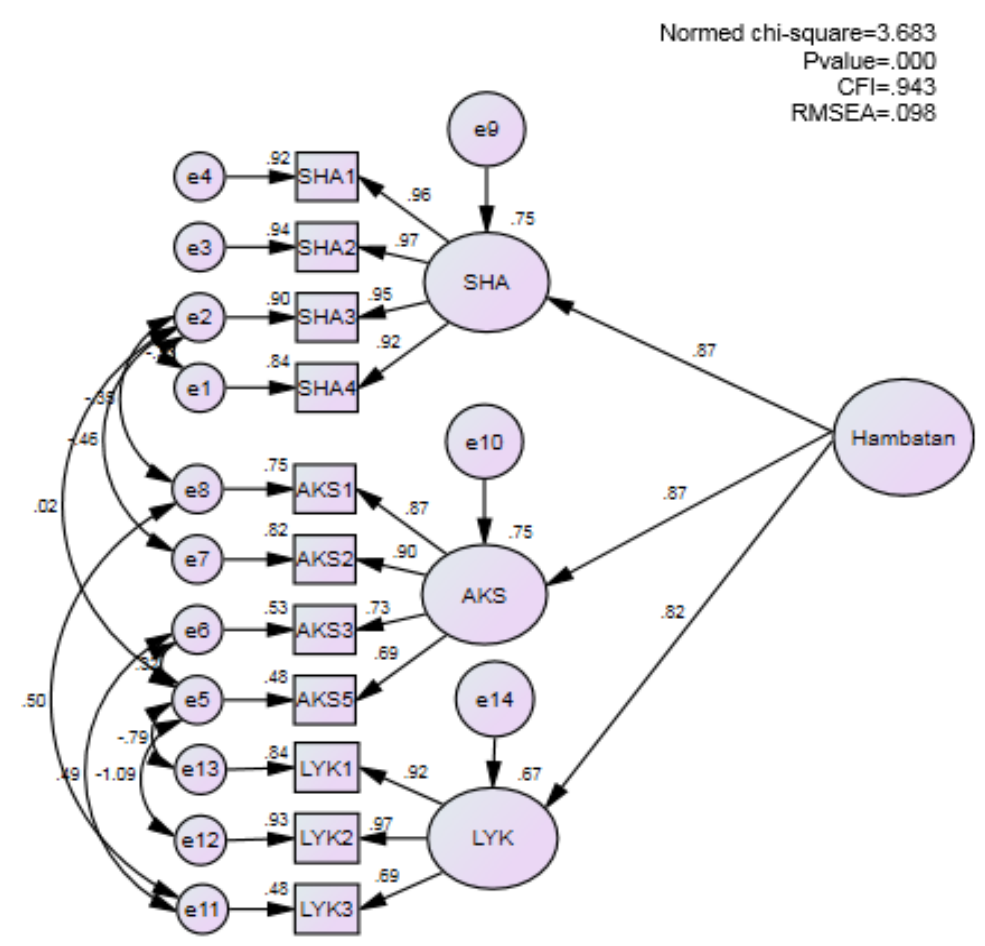

Figure 3.

Second order CFA penghambat pembiayaan (percobaan 2)

Hasil second order CFA memvalidasi tiga variabel seperti faktor agama, aksesibilitas yang rendah dan kelayakan yang rendah berada dalam fit indices yang terbaik sebagai faktor 


\section{Hartomi Maulana}

\section{Mohammad Zaenal Abidin}

penghambat pembiayaan pada jasa keuangan di karisedenan Madiun. Hasil ini sejalan dengan faktor penghambat pembiayaan sebagai konstruk yang multidimensional yang meliputi faktor agama, aksesiblitas yang rendah dan kelayakan yang rendah. Hasil ini mengintegrasikan dengan faktor penghambat pembiaayan yang ada seperti studi yang dilakukan oleh by Demirguc-Kunt et al. (2008) dan World Bank (2010).

Hasil dari faktor analisis mengungkapkan bahwa faktor alasan agama dianggap sebagai faktor penghambat terbesar dalam mengakses pembiayaan dengan kontribusi sekitar 31 persen. Studi ini konsisten dengan studi penghambat pembiayaan sebelumnya seperti yang dilakukan oleh Demirguc-Kunt et al. (2008) yang menyimpulkan walaupun kelompok tertentu yang berpenghasilan rendah memiliki akses, tetapi mereka memilih untuk tidak menggunakan layanan keuangan karena alasan agama. Sebagian Muslim menyadari bahwa produk keuangan konvensional mengandungi bunga atau riba, maisyir, gharar yang dilarang oleh prinsip-prinsip keuangan Islam (Karim et al., 2008).

Faktor lain yang menghambat pembiayaan adalah aksesibilitas yang rendah. Hasil faktor analisis menunjukkan bahwa aksesibilitas yang rendah berkontribusi sekitar 28 persen dari keseluruhan faktor penghambat pembiayaan. Hasil ini menegaskan hasil studi sebelumnya oleh Jha et al. (2014) yang menemukan bahwa hambatan aksesibilitas seperti jarak geografis ke bank, tidak memiliki outlet ATM di daerah terdekat dan sebagainya diidentifikasi sebagai faktor penghambat pembiayaan. Selain aksesiblitas yang rendah, kelayakan yang rendah merupakan faktor penghambat pembiayaan dan faktor tersebut menjelaskan 23 persen dari keseluruhan faktor penghambat dalam studi ini. Menurut suvei BRI's MASS (Microfinance Access and Services Survey) pada tahun 2002 menemukan bahwa kurangnya dokumentasi terlihat menjadi kendala utama yang dihadapi oleh kelompok berpenghasilan rendah dalam mengakses pembiayaan dari layanan perbankan di Indonesia (World Bank, 2010).

\section{SIMPULAN}

Kesimpulanya, analisis studi ini dieksplore untuk mencapai model second order yang valid dengan model fit pada data dan juga mendukung keluasan teori dari model tersebut. Uji second order CFA secara tidak langsung mengindikasikan bahwa tiga variabel dengan 11 item (dokumen rumit, jaminan ketat, pembatasan usia, jarak yang jauh, jauh dari outlet ATM, persepsi ditolak, staf kurang ramah, terdapat riba, gharar dan maisyir) tersebut merupakan kesesuaian yang terbaik dalam mengukur faktor penghambat pembiayaan. Dengan hambatan pembiayaan yang teridentifikasi, studi ini memungkinkan akademisi, praktisi dan pembuat kebijakan semakin menyadari faktor-faktor yang dapat mencegah usaha mikro dalam mengakses pembiayaan dalam konteks lembaga perbankan Indonesia. Dengan 


\section{Jurnal Manajemen Teori dan Terapan \\ Tahun 12. No. 3, Desember 2019}

mengetahui penghambat pembiayaan, diharapkan praktisi (perbankan) dan pemerintah dapat membuat kebijakan yang bisa meminimalisir penghambat pembiayaan.

\section{REFERENCES}

Adewale, A., Huq, A., dan Mydin, A. K. 2012. A Measurement Model of the Determinants of Financial Exclusion among Muslim Micro-entrepreneurs in Ilorin. Journal of Islamic Finance, IIUM Institute of Islamic Banking and Finance, 1 (1): 30-43.

Bank Indonesia. 2000. Laporan Perekonomian Indonesia Tahun 2000.

Beck, T., Demirgüç-Kunt, A., dan Peria, M. S. M. 2008. Banking services for everyone? Barriers to bank access and use around the world. World Bank Economic Review, 22(3): 397430. doi:10.1093/wber//hn020.

Byrne, B. N. 2010. Structural Equation Modeling with AMOS: Basic concept application, and programming. 2. Mahwah, NJ: Erlbaum.

BPS. 2016. Statistical Yearbook of Indonesia 2016. Badan Pusat Statistik - Statistics Indonesia. BPS. 2017. Statistical Yearbook of Indonesia 2017. Badan Pusat Statistik - Statistics Indonesia.

Demirguc-kunt, A., and Klapper, L. 2012. Measuring financial inclusion. The Global Findex Database. Policy Research Working Paper, 6025. April: 1-61. doi:10.1596/978-0-82139509-7.

Demirguc-Kunt, A, B, T., dan Honohan, P. 2008. Finance for All: Policies and Pitfalls in Expanding Access. The World Bank.

DeLamater, J. D., dan Myers, D. J. 2011. Social Psychology. Belmont, CA: Wadsworth Carnegie Learning.

Hair, J. F., Black, W. C., Babin, B. J, dan Aderson, R. E. 2010. Multivariate Data Analysis (7th edn.). New Jersey: Pearson Prentice Hall.

Hu, L., dan Bentler, P. M. 1999. Cut-off criteria for fit indexes in covariance structure analysis: conventional criteria versus new alternatives. Structural Equation Modelling. 6(1): 1-55.

Jha, M., Samantha, A., dan Calverley, J. 2014. Financial Inclusion: Reaching the unbanked. Special Report, Standard Chartered, (September)

Karim, N., Tarazi, M., dan Reille, X. 2008. Islamic Microfinance: CGAP, (August).

Ledgerwood, J., dan Gibson, A. 2013. The Evolving Financial Landscape. In J. Ledgerwood, J. Earne and C. Nelson (Eds.), The New Microfinance Handbook, A Financial Market System Perspective. Washington, D.C: The World Bank.

Mahmud, Z., dan Huda, A. 2010. SMEs' access to finance: an Indonesia case study. In D. Harvie, S. Oum\& D.A. Narjoko (Eds.), Small and medium enterprises (SMEs) access to finance in selected East Asian Economies. ERIA Research Project Report, No.14.

Milfont, T. L., dan Duckitt, J. 2004. The structure of environmental attitudes: A first- and second-order confirmatory factor analysis. Journal of Environmental Psychology. 24 (3). 289-303. http://doi.org/10.1016/i.jenvp.2004.09.001. 


\section{Hartomi Maulana}

\section{Mohammad Zaenal Abidin}

Mustapha, B., dan Bolaji, B, Y. 2015. Measuring Lecturers Commitment Scales: A Second order Confirmatory Factor Analysis (CFA). International Journal of Education and Research. 3(3): 505-516.

Nunnally, J.C., dan Bernstein, I.H. 1994. Psychometric Theory (3rded.). New York: McGraw Hill

OIC Outlook Series. 2012. Islamic Finance in OIC member countries. SESRIC, May. Retrieved on http://www.sesrtcic.org/files/article/450.pdf.

World Bank. 2011. East Java Growth Diagnostic Identifying the Constraints to Inclusive Growth in Indonesia's Second-Largest Province. Jakarta: World Bank Office Jakarta.

World Bank. 2010. East Java Growth Diagnostic Identifying the Constraints to Inclusive Growth in Indonesia's Second-Largest Province. Jakarta: World Bank Office Jakarta. 